\title{
O menino e o silêncio ${ }^{1}$
}

\author{
Daniel Conte
}

Resumen: basado en la obra As aventuras de Ngunga, de Pepetela, se busca en este ensayo evidenciar el comienzo del quiebre de un silencio secular. Silencio impuesto por la tradición africana que, dentro del proceso de independencia, fue uno de los obstáculos para la organización sistemática de resistencia anticolonial. En el momento que Ngunga sistematiza la ruptura con la tradición, al quebrar el silencio, es posible resignificar el orden social y pensarse como un Ser-colonizado constituído, también, por el Otrocolonizador y, entonces, universalizarse. Gaston Bachelard, Ernest Cassirer, George Steiner sirven de base teórica para la argumentación.

Palabras-chave: Identidad, Pepetela, Ngunga, Tradición, Silencio.

1 Uma possível introdução

O anseio provocava uma quietude de reação e o sol ia alto nos céus de Benguela quando os soldados do MPLA $^{2}$ responsáveis pela divisão do Serviço de Cultura e Educação do Movimento romperam os limites da Base Avançada do Leste, empunhando suas akas, acomodados em um jeep verde-oliva, para distribuir os 300 exemplares mimeografados d'As aventuras de Ngunga por todas as partes do território angolano que comportassem alguma das bases do Partido. A essa altura da História, este espaço estava mergulhado numa guerra anticolonial sangrenta e irrefreável. Era 1973. Já se iam quase doze anos de luta. E ainda faltavam dois para a independência.

A ideia primeira da publicação do texto de Pepetela era a de auxiliar na alfabetização dos pioneiros do MPLA; o alto índice de analfabetismo e a dificuldade na comunicação entre os pares da resistência ao colonialismo português faziam com que emergisse uma dificuldade que antes não era tão perceptível como se configurava naquele momento da História: a palavra escrita tomava uma importância antes não tida. Numa sociedade tradicional, que durante séculos perpetuou o canto poético de sua cultura, explicando a gênese da vida e da morte, conquistando territórios e afastando os kazumbis ${ }^{3}$, sempre pautada sobre a oralidade ordenadora do coletivo, para essa organização social, a importância em que se alicerçava o verbo posto no branco do papel soava estranho e paradoxal.

$\mathrm{Na}$ mesma cadência que se tentava reforçar os valores nacionais para superar as diferenças étnicas e formar uma espécie de mosaico identitário, erguia-se a necessidade da revisão dos códigos tribais, das concepções arcaicas de sociedade e das manifestações relacionais dentro de organizações sociais que tinham um funcionamento que não condiziam com a realidade que se lhes apresentava.

Sensível a essa rede simbólico-imaginária, Pepetela, num movimento horizontal aos acontecimentos históricos, tece uma narrativa em que vai elevar as questões pertinentes à mudança a um patamar de audibilidade. Traz à percepção da sociedade angolana, e mais especificamente àqueles que estão dentro da formação discursiva do MPLA, as modificações necessárias para a continuidade e o êxito da luta anticolonial, alterações que eram vistas como transgressões dos conceitos tribais de sistemas mítico-arcaicos. As aventuras de Ngunga é uma narrativa de movimento: a movimentação de um menino dentro dos conceitos da guerra e dentro dos conceitos das tribos. Órfão de pai e mãe, Ngunga, com 13 anos de idade, cresceu dentro de uma ideologia libertadora, incluído num discurso de libertação. Ele não aceita os valores impostos pelos Sobas ${ }^{4}$, pela esterilidade das palavras lançadas ao vento e se refugia e se esconde na retidão ética. O texto de Pepetela

\footnotetext{
${ }^{1}$ Pra Nanda e pro Jeferson, pela ressignificação da vida.

${ }^{2}$ Movimento Popular de Libertação de Angola.

${ }^{3}$ Kazumbis: almas ou espíritos de pessoas mortas.

${ }^{4}$ Denomina-se Soba o mais velho da tribo, aquele que leva consigo a tradição.
} 
é publicado com a missão de "reconstruir no campo ideológico uma identidade angolana que se harmonizasse com os processos de reconstrução nacional estabelecidos pelo MPLA (SILVA, 1980, p. 594).

Nesse contexto, as conjunturas econômica e social não eram das melhores, já exaustos em razão dos doze anos passados desde o início da primeira guerra de libertação, os angolanos viam uma luz perdida no horizonte, pois a força militar portuguesa entrava em contradição, abalando as estruturas relacionais não só das forças armadas, mas dos partidos políticos institucionais da metrópole. Portugal afrouxava o nó e reconhecia, aos poucos, a autonomia de suas colônias na África, começava-se, então, o desenho do fracasso colonizador. A população angolana não fazia ideia do que a História lhe reservava, tampouco, ainda, do quanto haveria de lutar para conquistar a soberania nacional, quando leu por vez primeira as histórias de um garoto aparentemente fraco, mas que trazia consigo todo o peso de uma cultura em revolução, ou seja, Ngunga era o portador, levava em suas palavras tudo aquilo que os portugueses tentaram corromper durante anos de colonialismo: o imaginário de uma nação, os valores que compunham a historicidade de sua percepção de mundo, a luz que indicava, mesmo que minimamente, o sendero a seguir.

Pensando em caminhos, em possibilidades, é bom trazer à discussão Gaston Bachelard quando ensina, na sua poética, que a chama de uma vela "nos leva a ver em primeira mão" [e que com ela] "temos mil lembranças" (1989, p. 11), fazendo reavivar uma memória muito antiga; Ngunga é essa aproximação contrária, pois se a chama estimula o filósofo a olhar e a sonhar, tirando-o da solidão, rompendo o silêncio perturbador e inserindo-o num contexto de concretude verbal, posso pensar que isso ocorre com o personagem quando contempla e sonha seu país com a guerrilha presente, mas o detalhe é o caminho. Ele faz o movimento inverso: sai do Eu, do imaginário infantil-colonizado no qual está espacializado, e simula perder-se no nós, no social, enquanto a chama, sensível e leve, condiciona o filósofo-sonhador-de-vela a abstrair-se do nós e fixar-se, a partir do momento pactual entre ele e o fogo brando, no Eu, no fantásticoegoísmo-individual. É dizer que se a chama da qual nos fala Bachelard é um mundo para o homem só, a guerra não cabe aí, porque apresenta-se justamente ao revés, e também a voz descontente do personagem aí não se enquadra, pois é ícone da guerrilha. No entanto, ao que se refere ao conselho de toda chama que é "queimar alto, sempre mais alto para estar certa de dar a luz" (BACHELARD, 1989, p. 12), pode-se pensar em uma analogia possível, ao passo que Ngunga decide pulverizar-se e perder-se no coletivo para lutar sempre mais e mais, na certeza de alumbrar não a luz necessária para a recuperação de uma organização fantástico-individual, mas a luz que vai iluminar as trevas em que está mergulhada sua nação. Uma luz que iluminará o inconsciente coletivo numa espécie de compilação dos elementos fantástico-ideológicos dispersos na memória do seu povo e que a organização funcional da colonização tratou de esfacelar.

$\mathrm{O}$ que é importante perceber é que o menino foge à grosseria das palavras que se esterilizam pela vulgaridade dos sentidos, como mostrarei mais adiante, pela banalização de sua habitação em que o discurso se torna uma malha descomposta de valor e a produção de sentido é inabilitada pelo excesso da vaidade.

O velho lamentou-se da fome, dos celeiros vazios. Mandou trazer um pratinho de pirão para o comandante. Para os outros nada havia. O comandante teve de dar dois metros de pano e outro pratinho apareceu. Ngunga não falou. Começava a perceber que as palavras nada valiam. Foi ao celeiro, encheu uma quinda grande com fuba, mais um cesto. Trouxe tudo para o sítio onde estavam as visitas e o Presidente Kafuxi. Sem uma palavra, poisou a comida no chão. Depois foi à cubata arrumar suas coisas. Partiu sem se despedir de ninguém. O velho Kafuxi, furioso, envergonhado, só o mirava com os olhos maus (PEPETELA, 1981, p. 16).

Nessa passagem, o silêncio é o que produz sentido dentro da guerra. A palavra do Presidente é relegada à esterilidade. A secular tradição que assegura a incontestabilidade de Kafuxi e de seu discurso está a ruir, não se apresenta com o grau de coerência necessária para dar logicidade àquele espaço. A condição primeira da palavra - cárcere privado do silêncio - de carregar consigo o aspecto espaço-temporal da criação e derrocadas de mundos está violada, não se respeitando sua condição mítico-sacral. De acordo com Cassirer deve "haver alguma função determinada, essencialmente imutável, que confere à Palavra este caráter distintivamente religioso, elevando-a desde o começo, à esfera religiosa, à esfera do sagrado" (CASSIRER, 1972, p. 65), o que não se tem na verticalização do personagem que representa o sistema que está a esfacelar-se, que representa os valores que Ngunga se propõe a pensar e, pensando-os, já está rompendo com o paradigma secular de aceitação coletiva, bem porque, para pensar-se, é fundamental que se esteja ocupando um silêncio contemplativo.

A ação de trazer o fubá escondido é um desrespeito enorme, se vislumbrarmos desde uma perspectiva tradicional, o Soba é afrontado, é desmentido diante da sociedade e sua autoridade desfeita, uma atitude inadmissível, o que poderia levar a uma desarmonização generalizada. Mas não é essa a leitura se pensarmos 
na luta anticolonial de libertação, pois libertar-se do colonizador e do seu processo de domínio é, necessariamente, naquele período da História de Angola, libertar-se dos valores tribais, da fixação da incontestabilidade da palavra daquele que, tradicionalmente, é irrespondível.

Valores que estão permeados da corrupção administrativa colonial e que trazem em si um mal congênito: o acúmulo, a mais-valia. Uma falha gravíssima que era rechaçada em primeiro grau nas formações políticas do MPLA, partido de cunho marxista-leninista e que agora, o escritor, traz com um viés de criticidade potencializada. É dizer que se Ngunga não tivesse tomado essa atitude, essa tradição antieuclidiana se perpetuaria. A deturpação dos códigos tribais mostra a não possibilidade da fixidez. Tanto a fixidez espacial, como a intelectual. $\mathrm{O}$ menino não para, exerce uma função migratório-construtiva em sua travessia. Estabelece um processo de criticidade e avaliação, e parte. É um viajante. Ele tem autoridade, porque conhece seu povo e sua terra, perpassa as fronteiras humanas, supera diferenças sócio-culturais e exerce duas tarefas cruciais: a de descobrir seu país em sua totalidade diversa e construir-se como um Outro-eu-dele, já consciente dos equívocos conceituais.

É o professor Octavio Ianni, em seu texto A metáfora da viagem, que observa que toda viagem

[...] destina-se a ultrapassar fronteiras, tanto dissolvendo-as como recriando-as. Ao mesmo tempo que demarca diferenças, singularidades ou alteridades, demarca semelhanças, continuidades, ressonâncias. Tanto singulariza como universaliza. Projeta no espaço e no tempo um eu-nômade, reconhecendo as diversidades e tecendo continuidades (IANNI, 1990, p. 146).

No caso de Ngunga, a viagem o faz cada vez mais plural, o faz ter uma visão topográfica da sociedade. Uma pluralidade que era buscada dentro do Movimento de modo a fazer-se surgir o Novo-Homem angolano, inserindo-o em uma sociedade especial, se vislumbrarmos desde uma perspectiva antropológica. $\mathrm{O}$ homem que vai ultrapassar fronteiras com o olhar de viajante, o olhar descomprometido com a análise conceitual, mas erguido sobre ela e sobre a vontade da assimilação antropofágica daquilo que vê e nele não está. Quando afirmo que era necessário superar os valores tribais, relativizando o poder inconteste atribuído aos eleitos, significa que a revisão deve perpassar todos os pontos, e dentre eles, um dos mais cruéis: o tribalismo, um conceito antigo, existente na estrutura social e no imaginário africanos, mas reelaborado de forma extremamente perversa pela máquina colonizadora que produzia tensões adversas de alimentação ao ódio coletivo $^{5}$. Uma intolerância étnica que emperra o movimento da resistência. Impede um melhor desempenho das forças do MPLA, devido ao fomento dessa alteridade xenofóbica sistematizada nas frentes de batalha e pulverizada, principalmente, pela UPA. A distribuição da narrativa de Pepetela vai em busca da sedimentação de valores outros que não os que vigoram como sectários e aporéticos. Como mostrei, as palavras de Kafuxi, estéreis palavras, negando a comida, são de alta significância, já que não aproximam os fatos da possibilidade bélica. A tática de Ngunga é evidenciar as notas dissoantes e partir, justamente porque a História, através das palavras, estava tomando, por vezes, caminhos tão cruéis como o colonialismo declarado e o velamento da possibilidade do arranjamento do real se esvai. Não há espaço para o simulacro dentro do processo de

\footnotetext{
${ }^{5}$ Faz-se de bom tom que eu explique a questão do tribalismo: já registrei, em outra oportunidade neste trabalho, que à chegada de Diogo Cão à foz do Rio do Congo no final do século XV, deu-se a conhecer o intenso mercado comercial existente entre os africanos e os árabes, em que a língua do Magreb funcionava como o idioma gentílico. Sabe-se que as culturas em que inexistia o limite geográfico como definidor espacial, como elemento de barreira imaginária, faziam-se perceber através de sua força. Em muitos casos, na maioria deles, a escravidão era a forma de delimitação e ostentação de seu poder. Antes mesmo da conquista da América e da África, parte da humanidade padecera sob a escravidão econômica romana. Os demais casos eram uma espécie de escravismo doméstico - e aí se inclui a África Negra -, em pequeno número, que sustentava a supremacia de famílias ou de certas etnias, conforme Marc Ferro (2004). Excessão a isso era o caso do domínio árabe que se estendeu do século IX ao século $\mathrm{XV}$, ínterim em que os "escravos representavam um produto de exportação para o norte do continente [...] a maioria das vítimas eram mulheres e crianças" (FERRO, 2004, p. 118). Dentro dessa sistemática, guardadas as devidas diferenças étnicas e proporções sistêmicas, o colonizador age como elemento catalisador do ódio adormecido, bem porque o que deseja esse colonizador é o agravamento dos conflitos étnicos, de modo a cooptar partícipes da causa colonialista. Com o triunfo do Islã, é bom que se diga, há a bipolarização da estrutura social e os árabes se diferenciam dos não-árabes. Isso quer dizer que todos aqueles que caíssem vencidos em batalha ficavam sujeitos às obrigações diversas. Dentre eles "aqueles que têm pele branca (circassianos, armênios e eslavos) e aqueles que a têm mais escura (no Alto Nilo e na África)", conforme Ferro (2004). Daî surgem os estereótipos, figuras criadas justamente, imagino, para gestar uma espécie de fragmentação entre os escravos. As palavras de Ferro evidenciam muito bem essa ideia: "Mas, pouco a pouco, os estereótipos contrários tomam a dianteira - os mais difundidos concernem aos negros, que eles mesmos reproduzem: És um zanj por teu nariz e por teus lábios, diz um africano a outro, e tu também, tu és um zanj por tua cor e por tuas axilas. Quanto às mulheres, elas têm muitos defeitos; quanto mais negras são, mais suas faces são feias e seus dentes pontudos [...] elas não podem proporcionar prazer algum por causa de seu odor e da grosseria de seus corpos" (FERRO, 2004, p. 123). E o discurso de inferiorização alheia se fixa no inconsciente coletivo, gestando arquétipos funcionais dos quais vão se aproveitar os colonizadores para efetivarem sua prática. $\mathrm{O}$ que significa que o dito pelo senso-comum de que os negros é que escravizavam os negros e que isso, por si só, justificava o escravismo e o tráfico negreiro, é no mínimo risível, patético e não leva em consideração as superestruturas e infraestruturas sociais, muito menos os mecanismos históricos gerenciados pela História.
}

Organon, Porto Alegre, no 47, julho-dezembro, 2009, p.177 - 205 
libertação e essa é a tarefa de Ngunga, escancarar o dissimulado a partir de uma perspectiva negativa e fragmentadora.

Daí a edificação do silêncio. Eis o processo de construção de um refúgio protetor da palavra, prostituída nas falas dos inabilitados verbais. A ininterrupta viagem de Ngunga vem se configurar como fuga à verborragia inestancável. O sentimento de frustração sempre explícito no discurso do menino evidencia a tênue fronteira entre ser calado e ser silencioso.

Só aceitara ficar e trabalhar porque o velho Kafuxi lhe falara. O velho convenceu-o com sua conversa sobre a comida dos guerrilheiros. Kafuxi era o presidente, quer dizer, era o responsável da população de uma série de aldeias. Mas depois da conversa que tinha ouvido, Ngunga ficou a pensar. Afinal o velho estava a apoveitar. Era mais rico que os outros, pois tinha mais mulheres. Além disso, tinha o Ngunga, que trabalhava todo o dia e só comia um pouco. Uma parte do seu trabalho, uma canequita talvez, ia para os guerrilheiros. Algumas canecas iam para sua alimentação. E o resto? [...] Tudo isso ia para o velho, que guardava para trocar por pano. Quando chegava um grupo de guerrilheiros ao kimbo mandava esconder o fubá. Dizia às visitas que não tinha comida quase nenhuma. [...] Ngunga pensava, pensava. Todos os adultos eram assim egoístas? (PEPETELA, 1981, p. 15).

Ngunga percebe que não condizem palavras e ações, a esterilidade das palavras do velho Kafuxi o desautorizam diante dos olhos do menino e se desfaz a probabilidade da coerência tradicional, o que reforça a ideia do questionamento. Essas ações desestabilizadoras são responsáveis pela continuidade da luta e da viagem. O que ocorre é uma espécie de peripécia do status quo tribal, como vimos anteriormente, quando Ngunga arrastou até a presença dos guerrilheiros o fubá que Kafuxi mandara esconder. Habitando o silêncio em sua totalidade analítica, o menino se coloca contrário às palavras do Presidente e se reconhece no discurso dos soldados, e é aí que inicia o processo de reação, ao qual me referi como peripécia, bem porque "é uma viravolta das ações em sentido contrário, e isso, [...] segundo a verossimilhança ou necessidade". [Assim o pioneiro se reconhece no discurso que alimenta a propulsão libertadora, porque o] "mais belo reconhecimento é o que se dá ao mesmo tempo que uma peripécia” (ARISTÓTELES, 1997, p. 30).

Definitivamente, Ngunga é um habitador de silêncio. Reconfigura o valor do estendido poético e busca romper o abismo que existe entre a palavra, seu significado e a imagem produzida. No momento em que disse da habitação do silêncio, referi-me à geração de uma outra prática que não aquela que compõe a malha social, objeto de crítica explícita na narrativa de Pepetela, mas de uma que é constituída da intuição imediata e da convicção vivida do funcionamento organizacional. De uma que vai, ao rever a historicidade tradicional, e em sua esfera (a de releitura) elevar "ao nível de exigência metodológica, a íntima relação entre o nome e a coisa, e sua latente identidade" (CASSIRER, 1972, p.17). Isso, o silenciar-se, é fundamental e estratégico dentro da compleição bélica. A fuga do poder da palavra de onde evadiu o sentido ainda é deturpador, avassalador, já que os atores sociais proclamam o verbo em suas formas mais diversas, carregados dos mais diversos sentidos, e esterilizam, muitas vezes, a comunicação, porque uma muralha é erguida entre a palavra e sua possibilidade. E mais vezes ainda ferem, ocasionando traumas históricos, levando os atores da História a habitar o silêncio e a produzir significação, então.

É isso que faz Ngunga quando a relação entre as linguagens verbais atinge um grau de equivalência grosseiro e abominável e quando o tempo ingressa nas inúteis colunas vermelhas à esquerda dos calendários que ele desconhece: em silêncio ele procura não ferir a palavra impronunciada que se apresenta pronta para alimentar seu excesso de sentido, pronta para alimentar a falta alheia de sentido. E a ação do guerrilheiro sobrepõe-se ao signo. Silencia e parte. E nessa viagem se vai constituir a plenitude da reação anticolonial. Essa viagem pode ser uma longa faina destinada a desenvolver o Eu. As inquietações, descobertas e frustrações podem agilizar as potencialidades daquele que caminha, busca ou foge. Ao longo da travessia não somente encontra-se, mas reencontra-se, já que se descobre mesmo e diferente, idêntico e transfigurado. Pode até revelar-se irreconhecível para si próprio, o que pode ser uma manifestação extrema do desenvolvimento do Eu. Um Eu que se move, podendo reiterar-se e modificar-se, até mesmo desenvolvendo a sua autoconsciência ou aprimorando a sua astúcia (IANNI, 1990, p. 157).

E é nesse constructo devaneante que o menino vai erguer-se, vai construir-se, diferenciando as aparências das essências, sabendo das dificuldades que se apresentam e sabendo de sua responsabilidade formadora: a de dar sentido à falácia palavrória que tensiona o Movimento de Libertação, que tenta impedir a verticalização da configuração do Novo-Homem. Embora inspirações viessem da América terceiro-mundista, com a completude mítica de Ernesto Guevara de la Serna, pairando sobre o continente, a constituição do NovoHomem angolano se apresentava delicada, a guerra e a terra destruída dificultavam o processo.

Mas Ngunga levava vantagem sobre qualquer outro que tentasse assumir para si essa tarefa: possuía a graça de ver a diversidade da unidade que se pretendia, através do filtro da infância - da condição 
naturalmente fantástica, detectando, concretamente, os efeitos impuros dos discursos dos adultos. Dentro dessa organização, a perpetuação se gera necessária e formadora do ciclo de resistência, o que faz com que se celebre o nascimento de cada homem, que em sua concepção, enquanto sujeito histórico, já nasce envergado ideologicamente.

Como se observa na passagem abaixo, a festa do nascimento do filho de Kayondo, traz a reboque a expectativa do que há por vir, o cheiro úmido das lavras recém-molhadas pelas chuvas, o gosto da carne fresca das palancas recém-caçadas, o prenúncio da sedimentação do rompimento definitivo com o colonialismo:

- É preciso ir longe buscar comida. Mas agora nossas lavras estão a começar a produzir e a situação vai melhorar. Conhece a mulher do Kayondo? Teve uma criança há dois dias. Um rapaz. O bebé não queria nascer, foi um grande trabalho. O Kayondo está todo contente, pois vai ter um homem na família. Já tinham tido três meninas, não conheces?

- Conheço - disse Ngunga

- Pois bem. Vamos cortar hoje o cordão umbilical, por isso haverá uma grande festa. Os pais de Kayondo já estão a prepara o hidromel e a comida. Tivemos sorte, pois caçamos duas palancas; carne não falta. O povo das outras aldeias já foi avisado, vai chegar hoje de manhã (PEPETELA, 1981, p. 7).

Com o surgimento do pequeno rapaz, que terá um dever já conhecido por todos, vem a fartura; é visível que as lavras já estão produzindo, a sorte está do lado do povo, a caça é farta e a alegria é geral, como mostram as linhas acima; por uma noite, num espaço de tempo recriado que foge ao real-cronológico, e que estabelece uma não-habitação-vulgar da palavra, todos esquecerão da guerra ao mesmo tempo que vão ritualizar sua sustentação. Esquecerão as contribuições para as frentes de batalha e irão comer e beber com fartura, só a alegria reinará. As mulheres dançarão a chinjanguila e os homens comprarão novas esposas e irão falar com gosto do rebolado de cada uma. Então as "vozes elevaram-se, os risos tornaram-se mais freqüentes, os olhos brilhavam mais. Os grupos faziam-se e desfaziam-se" (PEPETELA, 1981, p. 9). Tudo isso para que no dia seguinte, o pequeno Ngunga parta novamente para mais uma aventura nas matas angolanas, estendendo ainda mais o seu percurso, e para que o filho de Kayondo comece, ainda inconsciente, a traçar seu caminho de homem ideologicamente concebido.

Eticamente incontestável, Ngunga faz de Angola e de sua História sua própria alusão sem o cinismo dos adultos. É, pois, evidentemente, a simbolização da guerrilha e, por consequiência, do Novo-Estado em formação, uma vez que aparece sempre manifestando uma debilidade estética - o que pode ser estendido à fragilidade da natureza angolana depois de 500 anos de colonialismo ou, ainda, ao murmúrio de sofrimento de uma chama bachelariana - quando em verdade sua força e orientação ideológica são invulneráveis. Compilador e viajante, o menino detém em seu percurso os tempos de seu país, porque o "que é presente e o que é pretérito, próximo ou remoto, revela-se no relato, descrição ou interpretação daquele que aproveita os materiais colhidos em viagens, imaginando as formas de ser, agir, sentir, pensar ou imaginar que podem constituir o outro" (IANNI, 1990, p. 147). Ele é a voz revolucionária de Angola que, cansada e enrouquecida, nega-se a seguir entoando o fado lusitano, nega-se a seguir entoando a melodia dos Manikongos, para vislumbrar novas expectativas, outras condições.

Não quero conduzir a análise de maneira que se entenda que Ngunga é o fim das tradições, mas que ele é a demonstração da possibilidade de restauração do país, precedendo o surgimento de um Novo-Homem que será mais liberto das tradições e resistente à colonização. Um homem que deterá elementos e características tradicionais (pois, obviamente, não se trata de uma negação de origem), mas que transitará para fora do viciado-espaço-subjugado, um homem consciente de seus direitos na república popular e de seus deveres sociais.

Eis o cerne da questão e o problema está apresentado: quem é e qual a função específica do Novo-Homem angolano? Importante perceber que esta concepção de Novo não pode ser aleatória, partindo do lugar que se bem entender. Há de ter uma referência, um norte, como ensina Eliade, quando diz que "o fato de que o fim de um mundo - o da colonização - e a expectativa de um Mundo Novo implicam um retorno às origens" (1992, p. 67). Ora, se o retorno às origens é cíclico e inevitável - como evidencia o inteiriço véu de Clio (entre as musas a única que não leva o véu fragmentado) - a construção do Novo-Homem angolano há de estar embasada na análise crítica de sua História, o que significa que Ngunga tem o infindável trabalho de estabelecer a transição entre o passado e o presente numa espécie de avaliação contínua de sua viagemedificadora. Isso se dá na construção de seu discurso de revolucionário. E se nota em seu silêncio constituinte que se ergue em diferentes tons até sua declinação nominativa. 
Essa outra percepção da realidade, a que só tem o homem-viajante, o que supera fronteiras e pertence a todo território, como já disse antes, critica a relação de nauseamento social que se estende desde o início da colonização. Um exemplo disso é a plasticidade sintomática quando da insatisfação do menino em uma conversa travada à noite, na escola, com o professor União e Chivuala - seu colega de formação. No excerto, Ngunga aparece como habitador de silêncio de um espaço coletivo; vai falar, claro, quando se cria uma tensão atmosférica e quando suas palavras produzirão, de fato, algum sentido convergente com o Outro que o compõe, também em sua travessia, ou seja, suas palavras, em sua significação mais ampla, é o que fomentará o rompimento do silêncio costumeiro.

- Falas muito pouco - dizia União. - Não tens coisa para contar?

Ngunga dizia que não, o que vira era pouco. [...] O professor respondia que toda a gente tem qualquer coisa a ensinar aos outros. Até que, uma noite, resolveu dizer alguma coisa. Contou sua vida no kimbo do Presidente Kafuxi. No fim, o professor disse:

- Sim, eu conheço-o. A minha escola devia ser instalada lá. Mas ele recusou dar-me de comer. Dizia que já dava aos guerrilheiros, que não podia mais. O povo queria a escola, mas ele é o Presidente.

- Não pode arranjar outro presidente - perguntou Chivuala.

- A Imba falava-me da escola - disse Ngunga. - Ela queria estudar. Assim, perdeu por causa do pai.

- Kafuxi é o mais velho dali - disse União. - Ninguém tem coragem de o tirar de Presidente. Já no tempo dos tugas ele era o chefe do povo. Mas não pensem que é só ele.

E Ngunga pensou que havia coisas que não estavam certas. Mas ele ainda era miúdo... (PEPETELA, 1981, p. 26).

Há duas evidentes possibilidades de análise dessa passagem: a primeira é a que está num plano mais explícito, da construção discursiva dentro de uma formação ideológica. A segunda é a crítica fina e contundente sobre o processo de administração portuguesa na colônia e do como se perpetuou, condizendo a ação das autoridades tradicionais em espelhamento à administração lusitana. Vamos à primeira: está mais do que clara a relação do poder tradicional exposto no diálogo entre os personagens. O velho Presidente Kafuxi tem o direito adquirido de presidir o povo e ninguém o remove de seu espaço de poder, mas o que é relevante é que a tradição vem se erosionando, ao passo que essa tradição representada por ele já quase não encontra seu espaço de perpetuação, mas o de contradição que não alimentará sua permanência. Já quase está sendo superada por seu mais perigoso desafeto, o silêncio-gerador de palavras contestadoras, modificantes, habitadas de força rompante. E o espaço de poder vai, historicamente, desaparecer em função do discurso possibilitador da revolução que leva em si o poder da palavra oriunda da reflexão silenciosa que tem uma contundência muito maior que a estaticidade espacial.

É por esse viés que a palavra, quando habitada de sentido, é elevada à condição mítica e uma espécie de catarse plurivocal e polifônica, conforme Bakhtin (2004), emerge do discurso com a função natural dos mitos: estabelecer a ordem que falta no espaço coletivo, ao nível do sagrado-gerador, segundo Cassirer (1972), ou em tons de silêncio na prática de Ngunga. Isso não quer dizer que a resistência venha através do individualismo do menino, mas a questão está centrada na valorização enfática da palavra em sua condição cosmogônica-única que está atrelada a cada elemento que compõe a rede simbólica formadora do imaginário social. Para romper-se com os estratos arcaicos da sociedade, é necessário aliar-se elaborações discursivas coerentes dentro do espaço em que se é um dos atores.

É aí que surge o mito. É aí que se desconstrói o mito, numa espécie de idolatria indivíduo-coletiva. A palavra que domina total e plenamente seu espaço físico, existindo desde sua enunciação (CASSIRER 1972), vai levar o homem a ordenar e recuperar seu espaço interior, sua reserva íntima: a memória. Ao reconstituir mundos através da palavra, através da narrativa, dentro de uma outra perspectiva de poder que não a tradicional - pois a palavra proferida é uma espécie de externalização do mito social que cada homem leva consigo -, o ser que canta cria mecanismos generativos que estavam, até então, submersos no mormaço intelectual imposto pelo silenciamento mecanicista do sistema colonial. Nega-se, logo, a imposição representativa de um espaço-estéril (o da História) que tem habitado na sua existência memorial uma imagem já perdida ou que se vem perdendo. A resistência a essa perda está no habitar da memória, ou ainda quando Bachelard, em sua poética do espaço, afirma que é "exatamente porque as lembranças das antigas moradas são revividas como devaneios que as moradas do passado são imperecíveis dentro de nós" (BACHELARD, 1998, p. 26).

Nesse momento, as relações tribais se abalam e seu poder, aos poucos, deixa de ter um espaço, para construir-se como discurso revolucionário, como resultante de um recorrido histórico feito pelo menino Ngunga e que o vai levar a todas as paragens de sua viagem. E Ngunga traz uma memória repleta de espaços realmente habitados. Um espaço alheio que se tornou, também, seu. Seu decurso é permeado pelo exercício 
comparativo. Compara relações, atitudes, pessoas e práticas. É um processo interessante de constituir-se, pois a "comparação permite enriquecer a percepção das configurações e movimentos da realidade. Simultaneamente, estabelece os quadros da análise pormenorizada das situações, processos e estruturas em que se concretizam as configurações abrangentes ou os movimentos gerais" (IANNI, 1990, p. 149).

E é com essa possibilidade de analisar o todo e não só o estático, o fragmentado, que Ngunga vai dissecar o conjunto social em seu funcionamento mais amplo, em seu mosaico escandaloso de perpetuação da prática mentirosa do Presidente Kafuxi, por exemplo, que se protege com o código tribal [ao perpetuar-se em seu intransferível posto hierárquico], e exerce uma deturpada e anômala ação colonialista [de ódio, mesquinhez e humilhação] sobre seus semelhantes, e caminhar em direção à tomada plena da consciência revolucionária, refletindo sobre a realidade social de modo comparativo, analisando os diversos níveis da dominação funcional que rege a organização social. Ngunga traz uma política weberiana de autoconstrução, a da comparação.

\section{Uma análise possível}

1975 demoraria, ainda, dois longos anos para chegar quando a epopéia de Ngunga se deu a conhecer. O choro de criança que varreu os ares d'Angola foi percebido por todos os que freqüentavam as escolas avançadas do Movimento. O lamento vinha da ferida que atravessava o pé de Ngunga. A ferida que representava mais que a dor, mas sua superação. Mais que a dor, mas seu abalo estrutural possível. Nossa Luta, preocupado, questiona:

- Porque estás a chorar, Ngunga - perguntou Nossa Luta.

- Dói-me o pé.

- Mostra então teu pé. Vamos pára de chorar e levanta a perna.

- Ngunga, limpando as lágrimas, levantou a perna para a mostrar ao Nossa Luta. Este olhou para ela, depois disse:

- Tens aí uma ferida. Não é grande, mas é melhor ires ao camarada socorrista.

- Não quero.

- Se não te tratares, a ferida vai piorar. A perna inchará e terás muita febre.

- Não faz mal - disse Ngunga. - Não gosto de apanhar injeções.

- És burro. Agora, o socorrista não te vai dar injeção nenhuma. Mas depois, se tiveres uma infecção, então precisarás de injeções. Que preferes? (PEPETELA, 1981, p. 5).

Na representação do pé, a essência do menino e a tônica que perpassa o romance: o garoto tem o pé ferido, reclama porque dói, isto é, a pedra basilar que iniciará o movimento de construção da verdadeira casa de angolana, do Estado independente, está fendida, o que pode trazer a ruína não só do menino/homem, no caso da infecção, como também a derrocada de um ousado projeto para a construção de um Estado-Novo e autônomo.

Percebe-se, então, no começo da obra, a ameaça do não surgimento do Estado angolano e a chaga de um homem precoce, ícone de uma nação politicamente jovem, como definiu Angola o ex-ministro das relações exteriores, Venâncio de Moura, ao dar uma entrevista coletiva na VIII conferência dos Países-não-alinhados:

Já nascemos lutando. Tivemos que apreender a andar sozinhos, segundos após o parto. Tivemos que fazer em dez anos o que os outros levam décadas para fazer. Nossos inimigos não levaram em conta nossa infância e nos obrigaram a ser adultos quando muitas vezes a realidade e a história mostravam ser isso totalmente impossível (ÁFRICA, 1982, p. 28).

E Ngunga é justamente o reflexo dessa terra e Histórias descritas acima, por Venâncio de Moura, ou ainda, frágil e sensível como a chama bachelareana que pode ter sua existência comprometida por uma respiração mais ofegante. Uma criança que muito cedo apreendeu a caminhar e a conseguir o mel de todas as manhãs para o importante mata-bicho ${ }^{6}$. Um menino em quem Nossa Luta - é importante que se atente para a significação que traz esse personagem dentro da obra, já que assume para si todas as nuances da guerra, sintetizando o desejo coletivo e estendendo um grau acentuado de identificação - depositava toda sua esperança, respeitando não só as tradições das comunidades ameríndias e africanas, nas quais as crianças

\footnotetext{
${ }^{6}$ Primeira refeição da manhã.
} 
aparecem sempre com uma aura sagrada, pois atuam como o elemento perpetuador da espécie, mas também toda a dimensão política de um Estado restaurador das referências esfaceladas durante a colonização e mais: a relevância identitária do Novo-Homem angolano.

Impulsionado pela envergadura moral de Nossa Luta, Ngunga resolve embrenhar-se nas matas de seu país, o que já fazia, porém, agora, com mais afinco fará, superar o medo infantil de tomar injeções, passar pelos kimbos e romper com o que, até então, era senso comum, ou melhor, o menino Ngunga tinha uma missão a ser cumprida e era, indubitavelmente, a perpetuação dos valores defendidos por Nossa Luta, assim, tinha que transpassar as fronteiras dos medos infantis, o que o fazia abandonar, paulatinamente, sua condição. Interessante de se perceber que, depois da partida em busca do socorrista que trataria com propriedade sua chaga, Ngunga não volta a ver Nossa Luta, tão somente passa a vivê-lo. O que significa dizer que a imagem fixada de seu companheiro é a motivadora da epopéia do menino. A construção de sua identidade, o trajeto de composição de seu mosaico identitário, o percurso de sua incansável viagem é a busca do velho companheiro, portanto, a ressignificação da realidade de sua História não vem em tom conceitual - e é por isso que Ngunga rompe espaços construindo outros -, mas, criada num delicado processo de relações dialógicas com o Outro que se apresenta e que compõe o mosaico da travessia; essa relação possibilita transcender o espaço limítrofe do Eu, jogando-se no Outro, para, então, conceber-se.

Retomando Bachelard, na ocasião de seu estudo sobre a obra de Henri Bosco [a quem dedica A Chama de uma Vela], me recordo que se dirige ao poeta como "um mestre que conhece os devaneios da memória". [Ensina-nos que] "em muitos romances de Henri Bosco, o lampião é, em toda acepção do termo, um personagem [ou ainda que] o lampião tem um papel psicológico em relação à psicologia da família” (BACHELARD, 1989, p. 23). As palavras que parecem deslocadas dentro da argumentação que se eleva aventam a perfeita possibilidade de Nossa Luta estar representado por esta chama organizadora do microespaço. Ele tem um papel importante em relação à casa e em relação à família. Ele tem um papel importante para a continuidade da guerra e para a não deserção de Ngunga do caminho da regeneração das tradições.

E essas tradições das quais se desprende Ngunga, na medida que desenvolve o decurso da tomada da consciência, serão, em verdade, a representação de sua primeira guerra de libertação. É interessante trazer um excerto d'As aventuras de Ngunga: uma mitologia invertida?, da professora Maria Teresa Gil Mendes da Silva, quando diz que a

[...] personagem Ngunga recorda a figura do herói da fábula tradicional angolana que, como nos ensinam os antropólogos que se ocuparam de África, é o herói mítico que antigamente fundava as novas comunidades (é clara a alegoria neste caso). Mas a intenção de Pepetela é, contrariamente ao que acontecia com o mito do herói fundador, criar uma nova solidariedade, horizontal, entre indivíduo e indivíduo, cujo cimento ideológico não seja dado pelas classes de idade ou pelas famílias de origem, mas pelos novos ideais e pelo facto de se sentirem unidos na mesma luta, que tem como finalidade última a criação de novas relações de produção (SILVA, 1980, p. 595).

A emergência da necessidade do Novo, ou antes, a superação do arcaico, concretiza-se e a mudança se configura como imprescindível para que se tenha, nesse outro país que se desenha, autonomia de locomoção. Para que se possa caminhar sozinho, à revelia da conceituação e do silenciamento impostos pelas grandes potências, estabelecendo, assim, novas relações de produção - a meta sempre de todos movimentos e revoluções. Ngunga é, por fim, o marco-que-flutua entre a Nova-terra e o Velho-homem, o que vai entornar a vacuidade do discurso colonizador, com a pluralização de suas ações. O que vai entornar a vacuidade do discurso tradicional que deturpa o espaço do poder e move, em um movimento vertical, a anomalia herdada dos cinco séculos de administração colonial.

A senda percorrida até a tomada da consciência plena no final do romance, ao deparar-se com a aguda realidade desvelada por Wassamba e a autoconscientização de que a luta no país está só no início, e que sua seqüência depende única e exclusivamente de um outro alguém - anônimo e onipresente - faz com que Ngunga se desprenda da couraça de criança e assuma uma outra roupagem, a de homem. Uma alegoria que reflete o país, já que, paulatinamente, deixa a tutela portuguesa (o ser-colônia), para configurar-se como república, ou seja, a ação/trajeto da viagem empregada por Ngunga para o deixar-se levar e estender-se a um silêncio-produtor-de-um-sentido-revolucionário é semelhante à ação do rompimento do silêncio-sufocadorcolonial por que está passando o país e que vai levar à independência.

Exemplo incontestável de uma proba consciência ética, provida de toda dimensão do Estado-Novo e do Novo-Homem, traz em si essa força coletiva, a admiração do todo social, uma vez que suas ações são, visivelmente, representações de justiça e de soberania. Não uma soberania exclusivamente hierárquica, mas 
uma soberania em que há espaço para relações outras que não aquelas que o fizeram, em inúmeros episódios, sofrer. No desfecho final, no instante em que a moralidade ideológica do MPLA está decalcada em sua totalidade na narrativa, e só não se caracteriza como trágica porque Wassamba age como um elemento harmonizador, dotado de sensibilidade e lucidez potencializadas, aí, Ngunga se pluraliza e abre mão de ser-ele para ser-todos, diluindo-se na mata, tendo o nome roubado pelos ouvidos da menina e pelo vento que vadiava por ali; naquele momento, sumindo numa auréola misteriosa como os antigos heróis míticos fundadores de novas comunidades, ele vai habitar o silêncio em suas amplitudes possíveis, pois

O homem santo, o iniciado, se afasta não apenas das tentações da atividade mundana, mas também da palavra. Sua retirada para a gruta da montanha ou para a cela monástica é a representação exterior de seu silêncio. Mesmo aqueles que são apenas iniciantes nesse árduo caminho aprendem a desconfiar do véu da linguagem, a rompê-lo para chegar ao mais real (STEINER, 1998, p. 31).

Fernando da Costa Andrade comenta que Ngunga é um protótipo de militante na busca nacionalista, diz, ainda, que "Ngunga é irreal como homem, mas constitui a realidade psicológica de um todo, a verdade íntima de cada militante que entende a revolução como dimensão universal para a definição nacional da liberdade e da justiça e do Novo-Homem" (COSTA ANDRADE apud PHYLLIS, 1986, p. 143). Ilustro essa imensidão íntima de Ngunga, a possibilidade da verticalização do devaneio, essa visão da revolução em uma dimensão universal para a definição nacional com uma passagem delicada por que passa o menino - depois de sua fuga da prisão da PIDE - e na qual o menino/homem se caracteriza como o homem/chama, uma vez que, sozinho, pôde "concretizar o ser de suas imagens, o ser de todos os seus fantasmas" (BACHELARD, 1989, p. 13). Diz o narrador que todas

[...] as pessoas de quem gostara e quem não gostara vinham-lhe à lembrança: os pais, Mussango, Kafuxi, Imba, Nossa Luta, Mavinga, Chivuala, União. Bons ou maus, todos tinham uma coisa boa: recusavam ser escravos, não aceitavam o patrão colonialista. Não eram como os G.E ou o cozinheiro da PIDE. Eram pessoas, os outros eram animais domésticos (PEPETELA, 1981, p. 41).

Essa travessia por que passa o personagem é o momento em que se desvela a verdade. Mesmo com todas as diferenças existentes, os atores da História angolana como Kafuxi, Mussango, União estão patamarizados pela sistematização do pensamento do menino. É fundante a sua percepção. É includente sua percepção. A criança, que em breve deixará de sê-lo, corrói conceitos e faz uma sistematização da praticabilidade filosófica outra que aparece, acaba - com essa reflexão - com todo tipo de conhecimento privilegiado, hierarquizante e enciclopédico. É anticatalográfico, antissectário, o que conseqüentemente o posiciona contra a tradição que se sustenta pela intocabilidade daquele que a conhece e domina suas nuances. E contra o colonialismo, que, numa prática apurada da parvice cartesiana e do cientificismo europeu do século XIX, perpetua-se. A palavra utopia, no discurso e prática de Ngunga, retoma sua significação clássico-antiga. O topos [lugar] antecedido pela negação prefixal u [nenhum] edifica a análise objetiva dos fatores que desenham a História africana, mais especificamente a angolana, nesse momento.

Como está visto, na passagem está evidente que, apesar dos defeitos intrínsecos de cada sujeito, apesar da diversidade, Ngunga trouxe da memória os que levavam em si a característica edificante do Novo-Homem - a condição de discernimento do bom e do ruim, do necessário e do supérfluo, do silenciamento reativo do nãocondicionamento. Quando atravessava os kimbos em viagem, perguntavam a Ngunga, onde ia? Respondia que queria ver a nascente do rio, a origem da guerra, espaço ideal para o fim da viagem. Mas está claro no fragmento que segue, sua decepção.

Ao dizer a aldeia donde saíra, um guerrilheiro exclamou:

O kimbo do Nossa Luta.

Sim, sim - disse Ngunga, satisfeitíssimo. - Onde está o Nossa Luta?

Morreu.

Morreu - Ngunga não queria acreditar. - Nossa Luta morreu?

Tinha morrido numa emboscada do inimigo. Os camaradas tinham-no enterrado perto do caminho. Ngunga sentiu-se ainda mais só no mundo. E disse a verdade: Afinal eu andava a procura dele. Era meu único amigo (PEPETELA, 1981, p. 17).

Quando dá-se ao conhecimento, desmorona. Era Nossa Luta o que buscava o menino, o lampião bachelareano que não se apaga e que deixa uma imagem construída, modelarmente, educadora, criteriosa. A viagem empreendida é uma espécie de busca da gênese, da elevação concreta dos conceitos e ideais 
defendidos, da mudança provável. O menino buscava o início coerente de tudo: de seu mundo, de seu tempo, de si mesmo. Queria encontrar aquele que lhe havia sugerido a viagem até o socorrista para que tratasse a chaga que o importunava. Era isso que buscava, sair de seu silêncio para ingressar num tempo-outro, o que fosse habitado por palavras fazedoras de revolução e não perpetuadoras de tradição, e Nossa Luta tinha essa autoridade: a de falar em nome da revolução, discursando e fazendo com que a palavra se convertesse "numa espécie de arquipotência, onde radica todo o ser e todo acontecer. Em todas as cosmogonias míticas, por mais longe que remontemos em sua história, sempre volvemos a deparar com esta posição suprema da Palavra" (CASSIRER, 1972, p. 64).

E é nessa relação sujeito/palavra/silêncio/sentido que surge potencialmente o gérmem de uma verdadeira Nação. Consciente, o menino é o ícone do Estado e da ideolgia do país, tendo o respaldo da organização da luta, por exemplo,

Os guerrilheiros insistiam para que ficasse uns dias com eles. Ngunga nunca na sua vida recebeu tantos presentes: um apito, umas calças, um pássaro de peito de fogo, um punhal. Agradecia a amizade, mas à noite chorava. Tinha arranjado outros amigos, mas eles não podiam tomar o lugar do amigo perdido. Foi Nossa Luta quem cuidou dele quando os pais foram assassinados, foi Nossa Luta quem o acarinhou e ensinou. E Ngunga chorava (PEPETELA, 1981, p. 19).

No excerto, é notável que as atitudes são de solidariedade com o amigo que sofre, gerando uma forma de relação só manifestada antes por Nossa Luta e não manifestada por Kafuxi - a de preocupação com o Outro que também me compõe, antes registrada no texto da professora Maria Teresa: "a nova solidariedade horizontal entre indivíduo e indivíduo". Outro viés importante é o do presenteamento, Ngunga nunca tinha ganhado tantos presentes, mas a materialidade não alivia sua dor. Essa simbologia, se formos nos debruçar sobre uma análise diacrônica, nos levaria há milhares de anos, às mais primitivas sociedades, mas o que é importante deixar claro é que todos os rituais que envolvem essas trocas são de cunho coletivo-organizacional e têm, por primeira função, reforçar os vínculos que se criam, os que estão em sedimentação. Ensina Arnold van Gennep que

Entre alguns ameríndios setentrionais (Salish, etc.), esta troca tomou a forma de uma instituição, o potlatch, executado periodicamente e pelos vários indivíduos cada qual por sua vez, assim como uma das obrigações da realeza entre os semicivilizados consiste em redistribuir aos súditos os presentes oferecidos [...] estas indas e vindas de objetos entre pessoas dão origem a um grupo delimitado e criam a continuidade do vínculo social entre as pessoas, com a mesma significação que a comunhão (van GENNEP, 1978, p. 44).

A passagem é importantíssima e muito significativa, pois a questão primeira dá-se na delimitação do grupo e em sua continuação. Ngunga é detentor da continuidade de uma sociedade que o acolheu com tal objetivo e consegue elevar-se sobre as dieferenças. Diferenças se acentuaram depois da Conferência de Berlim - fundante da retalhação geográfica africana. Gennep traz uma análise antropológica no que tange à troca de presentes, uma espécie de recorte longitudinal verticalizado, o que nos coloca em confortável posição para entendermos a atitude coletiva em função de Ngunga.

Evidencio o fato de que o presente oferecido ao Outro foi a mais recorrente das táticas dos colonizadores nos primeiros contatos, o que quer dizer que todo o processo construtivo seja ele construtor de uma dominação (no caso a colonização), seja construtor de uma reação a ela, necessita sempre uma aproximação mínima que seja - para o fechamento de uma espécie de tríade composta pelo Eu, o Outro e Um-outro-eumeu que vai surgir desse contato - muitas vezes bestializado e violento - e que vai dar a durabilidade necessária para que se prolonguem as relações até o nível da suportabilidade, ainda que seja essa suportabilidade um fator flutuante entre o poder de fogo e a imbecilidade antropofágico-maniqueísta do mais belicoso que há entre o Eu e o Outro. Voltando aos presentes de Ngunga, é bom reparar que, além de fortificar a relação entre seus iguais, que não o têm mais como um menininho andarilho e sedimentam o elo que os une socialmente, esses presentes são simbolicamente quatro objetos que permitem a mudança estética do menino: o apito, as calças, o pássaro do peito de fogo e o punhal. São exatamente os objetos usados por um adultovigilante-tribal, aquele que não está diretamente vinculado com a guerra em suas Frentes de ataque, mas o que serve como protetor das povoações, o que não usa a farda de guerrilheiro, mas tem uma tarefa muito maior: a de proteger a tribo, fazendo a ligação e o contato direto com as tropas de resistência: uma espécie de catalisador entre a ação do colonizador e a reação da resistência. Quando penso nesse aspecto, me parece que reforça ainda mais a ideia da consciência construída por Ngunga e da aceitação dessa consciência pela ordem social angolana que não acelera seu processo de iniciação à luta armada, mas o respeito necessário ao tempo 
que precisa para erguer-se, reativo à ordem humilhadora e carrasca, já que se evidencia aí, no oferecimento/recebimento dos presentes, o "hábito de munir o viajante, por ocasião de cada partida, um sinal de reconhecimento (pau, téssera, carta, etc.) que o incorpora automaticamente a outras sociedades especiais" (van GENNEP, 1978, p. 49).

Ngunga foi intrauterizado pela guerra quando mais necessitou e agora inicia a batalha para que o NovoEstado não se forme já egoísta e unilateralizado. Ele se caracterizará como o mais fiel representante da síntese angolana, uma geração que leva incorporadas em si as qualidades do Homem-surgente, dentre elas a lucidez e a consciência, porque "o pequeno Ngunga não sabia do que era capaz e do que não era capaz. E sabia também que não era capaz de fazer muitas coisas por isso não era vaidoso" (PEPETELA, 1981, p. 28). Esse homem reciclado que aparece sendo produto já da organização de resistência age como se tivesse uma tela fina que separa a minúscula contradição discursiva do montante, que detecta os grãos-do-palavrório-ludibriante do povo, relegando-os ao conhecimento coletivo, o que vai provocar ora uma reação organizada, ora um silêncio constitutivo.

É assim que faz quando observa os detalhes nos discursos dos mais velhos, dos detentores da secular tradição, capta os exageros e foge ao que denomino fenômeno da adequação coletiva, que seria, aproximadamente, a indiferença diante do aumento ou da atenuação de determinados feitos recontados pelos guerrilheiros, situação que, para os demais, parecia imperceptível, mas para ele não passava despercebida, porque tem uma visão objetiva e funcional da tensão bélica que vai gerar uma defesa imediata do discurso alheio. Quando acompanha o Comandante Mavinga em uma de suas viagens, percebe que de "dia para dia Mavinga aumentava um pouco ou o número de inimigos mortos ou a dificuldade da operação. Os que iam com ele parecia que não reparavam" (PEPETELA, 1981, p. 45). A sutileza da percepção era fortuito de Ngunga, não cabível a qualquer outro personagem. Daí ele percebe que Mavinga se caracteriza como um grande Comandante através do próprio discurso, obtendo, assim, o respaldo social que garante sua edificação bélica. Mavinga reelabora sua percepção do mundo, do seu Eu-pra-mim, fazendo com que esse Eu-quasecalado e despercebido se externalize conforme sua autoprojeção, bem porque "segundo Bakhtin, a minha aparência é sempre construída a partir da representação que o outro produz de mim: a autoconsciência do meu ser no mundo só se dá através da compreensão ativa e valorativa do outro que me enxerga enquanto corpo exterior que se destaca do seu entorno" (ZOPPI-FONTANA, 1997, p. 118).

Ngunga acreditava pouco nas palavras, segundo ele, porque se distanciavam demais da realidade, não continham mais a força sacra de sua origem, como nos disse Cassirer (1972), e como as palavras em algumas situações não eram minimamente verossímeis, ele trabalhava para que, naquele contexto histórico, elas fossem habitadas de sentido, ao menos nas novas relações que surgiam, com sua prática. Nesse ponto, o silêncio é o grande propulsor da resistência, uma resistência estendida aos colonizadores e aos angolanosesvaziadores-de-palavras, perturbadores de seu inquieto espaço, que prostituíam o verbo ante ameaça qualquer.

Quando capturado junto com o professor União, ele é levado a uma prisão da PIDE e silencia. Age em sua mudez, encarcera-se voluntariamente.

Ngunga ficou esquecido todo dia na sua cela escura. À noite abriram a porta e atiraram um homem lá para dentro. Não havia luz nenhuma e não o reconheceu. Mas descobriu-o pela voz, quando ele perguntou:

- Quem és tu?

- Chitangua! Camarada Chitangua? Eu sou o Ngunga.

- Sim, sou o Chitangua. Como estás, Ngunga?Mais ou menos. Quando foi preso? Hoje? O kimbo foi atacado?

Chitangua era um homem da tribo do Presidente Livanga, perto da escola. Não respondeu logo a seguir, quando o fez, foi a custo.

- Fui apanhado ontem à tarde quando ia ao rio. Hoje só vos apanharam a vocês dois. Com o tiroteio o povo fugiu para longe. Eles regressaram ao quartel. Bateram-me, bateram-me muito.

$[\ldots]$

- Mas que trabalho fez?

- Indiquei o sítio da escola. Fui até lá mostrar-lhes. Mas vocês defenderam-se bem. Eles queriam recuar quando perceberam que as vossas munições estavam a acabar.

- Então você é que nos traiu? Foi mostrar o sítio?

- Que queres? Senão iam bater-me.

Ngunga não respondeu. Um homem tão grande, cheio de força. Um covarde!

- Que vai ser de mim?[...] A culpa é do professor. Porque é que ele não fala? Só querem saber quais as instruções que o Mavinga recebeu. O União é que lhe lê as cartas, ele sabe. 
Ngunga tinha vontade de lhe bater também. [...] União, sim, União era um homem. Combateu até ao fim e sempre preocupado com a salvação de Ngunga. E agora se negava a ajudar os tugas a apanharem o comandante Mavinga. União era seu professor e amigo: o orgulho fez Ngunga esquecer o sofrimento (PEPETELA, 1981, p. 35).

O inefável, então, se apresenta. Ngunga, que cresce transcendendo fronteiras, vê-se obrigado a recuar quando está no espaço-limite da palavra e de sua habitação. Contempla os possíveis significados, aventa ordens diversas, norteia um discurso de repúdio à ação de Chitangua, mas abandona a linguagem, recusando, neste instante, as palavras e seus tons, jogando-se ao silêncio contemplativo - a mais apurada das produções de ação reativa. O evento é quase inverossímil para ele, custa a crer que um companheiro de guerra pode ter feito tal monstruosidade. Neste instante, uma mescla de raiva e conformidade o invade e a confissão de Chitangua abre a porta para a segunda e fundamental experiência de Ngunga com a realidade guerrilheira: a da consistência cruel da realidade que é lutar contra um exército superior em armas e homens. Com o tratamento recebido depois da captura e com a concreta traição de um camarada de kimbo, ressalta-se, também, embora relativizada agora, nesse excerto, a simbologia das oposições: forte $\mathrm{x}$ fraco/ colonialista $\mathrm{x}$ colonizado/ Portugal x Angola, denunciando pelos fatos a acentuação de um triunfo nacionalista-angolano.

A soberania nacional é viável, mas necessária se faz a educação despertadora de uma consciência nacional que rompa o silêncio a que não muito me referi neste texto: o imposto pela opressão colonizadora, o que verte da mordaça emudecedora dos quereres sociais, aquele que relegou os povos Kikongo e o Kimbundo ${ }^{7}$ a quinhentos anos de uma mudez supérflua. E essa quietude gera um ser-afônico, repetidor de gemidos guturais. E essa mudez impossibilitadora do sonho faz surgir homens como Chitangua ou como o cozinheiro da PIDE que, aos resmungos, repetia: “- Vocês julgam que vão ser independentes? - dizia ele - Estúpidos! Se não fossem os brancos, nós nem conhecíamos a luz elétrica. Já tinhas visto a luz elétrica e os carros seu burro? E queres ser livre. Livre pra quê? Para andares nu a subir nas árvores?" (PEPETELA, 1981, p. 134). Evidenciase a acriticidade do cozinheiro. Sua ingenuidade argumentativa, a não compreensão da própria História e a repetição de um arquétipo-discurso-violador.

Aqui cabe uma ressalva: a condição de Ngunga é a ocupação de um espaço de liberdade, revolucionário e desprendido das autarquias e autoridades tradicionais - diferente do Cozinheiro e de Chipoya, por exemplo, que ainda estão atrelados a uma concepção arcaica de visagem histórica e representam, de acordo com a classificação de Albert Memmi (1977), a fatia dos assimilados na organização social colonialista.

Eis a grande ponte que Ngunga terá que erguer para a totalidade de sua travessia: a ligação e a apuração crítica entre os dois silêncios angolanos, a ligação e apuração produtora de uma ressignificação social entre os que se silenciaram para reagir e os que foram silenciados para serem passivos de uma ação opressora e caladora.

Enclausurado em seu silêncio, Ngunga pensa em salvar União, pois fica aflito com sua condição de encarcerado. Poderia, se soubesse escrever, mandar-lhe um bilhete. Aí se depara com sua condição de analfabeto. Como iria combinar para fugirem juntos daquele inferno? Neste instante, odiou mais o Presidente Kafuxi por ter impedido a instalação do posto escolar, alegando falta de comida. Neste instante, sentiu a importância da escola - uma espécie de moral-ideológica do MPLA que reforçava em todas instâncias da luta, o fomento à escolarização de seus pioneiros, pautando a resistência sobre o ponto da intelectualização. A agonia não dura muito. Numa manhã em que as coisas não se definiam bem lá fora e o verde das árvores era menos verde, numa manhã em que o silêncio das armas era mais dolorido que de costume, o professor fora transferido de helicóptero para não se sabe onde. Só deu tempo para ouvi-lo ao longe, misturada sua voz com o barulho das hélices, "-Nunca te esqueça que és um pioneiro do MPLA. Luta onde estiveres, Ngunga!" (PEPETELA, 1981, p. 38), então, passou o imaginável: Ngunga, sem nada que o ligasse àquele trabalho escravo, preparou sua viagem e partiu.

Veio a noite. Escura, pois as nuvens tapavam a Lua. O cozinheiro já fora para casa. Ngunga saiu da cozinha e entrou na sala onde estava o chefe da PIDE. Este escrevia na mesa. A pistola estava pendurada na parede. Ngunga pegou nela e apontou-a para o branco. Ele ouviu o barulho e virou a cabeça. A primeira bala atravessou-lhe o peito. A segunda foi na cabeça. Ngunga foi ao quarto, apanhou a G3 e a FN que lá estavam. Com as três armas, saiu de casa e meteu-se na noite (PEPETELA, 1981, p. 39).

\footnotetext{
${ }^{7}$ Kikongos e Kimbundos são os dois povos mais representativos que compõem a Nação Bantu, responsável por ${ }^{1 / 4}$ do povoamento da África Negra, conforme Norberto Gonzaga (1965, p. 53). Os Kikongos são uma etnia do Norte que ocupa a região até a fronteira com o Zaire. É nessa região que se localiza Mbanza Congo, sede do velho reino do Kongo. Já os Kimbundos, habitam a região que abrange a Lunda e o Malanje, essa população também é chamada de N'golas.
} 
Ngunga escapa ao arame farpado, permanece ali enquanto existe uma possibilidade de juntar-se ao companheiro União, desaparecendo a possibilidade, Ngunga dá continuidade à sua viagem edificadora na procura de um Outro-eu-dele, já permeado de desejos de liberdade. Ao ampliar suas fronteiras, deixou na PIDE duas mãos bem cheias de tradição, levando consigo uma dor quase que incicatrizável e que iria movê-lo ainda mais na passagem da reconquista: a morte de um amigo como União - uma pessoa consciente que sabia usar o silêncio em prol da luta de libertação, o silêncio contemplativo que poucos dominam. O menino foge com intenção de encontrar o comandante Mavinga, mas isso não ocorre. Seu primeiro encontro é com o comandante Avança (desafeto de Mavinga), quem o recebe e o felicita pela fuga, mas impede-o de voltar atrás em busca de Wassamba - primeiro amor de Ngunga [calado pela tradição] - e também o impede de carregar consigo as armas que levou do quartel da PIDE. As atitudes do comandante traçam uma problemática de negação da qualidade do Outro, ou seja, diante de Ngunga, Avança está diminuído. Suas atitudes são negativas e o conduzem a um patamar de menor qualificação, o que já era sabido dentro do Movimento, pois os "guerrilheiros que o acompanhavam disseram-lhe para não se importar. Avança era invejoso e cruel. Os guerrilheiros não gostavam dele" (PEPETELA, 1981, 46).

Na sua apresentação ao comandante Mavinga, depois de dias de caminhada, Ngunga é recebido como um verdadeiro herói e idolatrado pelo povo que rendeu festas em sua homenagem. Aí começa o reconhecimento coletivo de um homem-precoce que é fundador de um Estado que aos poucos toma características outras que destoam daquelas projetadas pela administração colonial. Contudo, o que Ngunga queria estava a alguns dias de caminhadas dali - rever a pequena Wassamba era seu único desejo. Ao comunicar a vontade de viajar ao lado Mavinga, denuncia seu amor:

Os olhos de Ngunga pediam com tanta insistência que Mavinga teve pena.

- Deixo-te ir, se me disseres do que se trata.

O pioneiro baixou os olhos, envergonhado. Dizer? Sentiu ao mesmo tempo necessidade de contar a alguém o que lhe acontecia. Porque não a Mavinga? Quase sem querer as palavras começaram a sair da sua boca. E falou de Uassamba, da vontade de voltar a ver, de lhe falar, de saber seu nome.

Mavinga riu, riu.

- Já? Só tens treze anos e já te interessas pelas raparigas? Tu és só miúdo na idade e no corpo, afinal.

- Posso ir? Perguntou Ngunga.

- Está bem. Agora também a quero conhecer! - respondeu o Comandante, rindo. E entregou mais uma caneca de hidromel a Ngunga (PEPETELA, 1981, p. 48).

Assumindo já uma postura não mais de menino e tendo o reconhecimento daqueles que constroem a nova ordem social, Ngunga volta a andar em busca do novo, transcendendo limites, erguendo novos paradigmas. Assim, com a permissão e o auxílio de Mavinga, ele encontra Wassamba. Antes mesmo de travarem um primeiro contato, Wassamba desconcertou-o ao sustentar um olhar "que o pioneiro não agüentava" (PEPETELA, 1981, p. 51). O primeiro diálogo dá-se perto do rio, quando a menina vai buscar água.

- Como te chamas?

- Uassamba.

- Queria falar contigo. Da outra vez, quando fui à Seção, quis voltar aqui mas não foi possível.

Ela riu

- Eu sei o Comandante até ralhou contigo - ela ria baixinho, os olhos no chão.

- Sim, queria ver-te, falar-te...

- Falar o quê?

Ngunga olhou para ela, admirado, pensativo (PEPETELA, 1981, p. 39).

As palavras naquele instante não se faziam necessárias. Ngunga falava já pelo visível desconcerto, e ela, pelos "olhos de gazela". Desiludido com a terra injusta regida por homens - desrespeitadores-de-palavras, o mundo desmorona de vez para Ngunga quando descobre que Wassamba, o grande amor de sua vida e a única pessoa que seria capaz de fazê-lo parar de viajar, é comprometida. E logo com Chipoya, o Presidente do kimbo. Totalmente desconcertado, refugiado em sua reserva íntima, não suporta o peso exagerado que leva a tradição, tenta reagir, mas tudo parecia voltar-se contra ele, o mundo havia caído na sua cabeça e tal era o peso que não podia ao menos levantá-la para reparar "nas lágrimas brilhando nos olhos de gazela" (PEPETELA, 1981, p. 50), enquanto Wassamba explicava sua condição: "Casei há dois meses. Sou a quarta mulher dele" (PEPETELA, 1981, p. 52). Outra vez a inefabilidade se faz presente para o menino.

Ngunga encostou-se a uma árvore. Por que o Mundo era assim? Tudo o que era bonito, bom, era oprimido, esmagado, pelo que era mau e feio. Não, não podia. Wassamba, tão nova, tão bonita, com aquele velho? 
Lá por que ele a comprara à família? Como um boi que se compra ou uma quinda de fuba? (PEPETELA, 1981, p. 52).

O que mais perturba a sensibilidade revolucionária do menino não é só perda da possibilidade norteadora que lhe toca a Wassamba, mas a coisificação, a objetalização da mulher que o colocou em rotação universal, elevando a tradição ao mesmo nível das práticas coloniais, igualando colonizador e colonizado numa espécie de bestialidade existencial. A perturbação geradora de um discurso sistematizado de revolta conduz Ngunga ao único lugar possível para a reação necessária: o silêncio. O silenciamento contemplativo será o próximo ponto de parada do menino, fim da viagem. Começo de outra, mais dolorosa e mais lenta e tão significativa quanto a primeira que se encerra. $\mathrm{O}$ que é importante notar nessa passagem é a visão global que tem, este Novo-Homem, da realidade que se lhe apresenta. Definitivamente Ngunga não é fragmentado como é a tradição e como é a administração colonial, ele percebe o inteiro, o completo. Para ele, a História não se dá com uma simples sucessão de eventos. Para que construa uma História - no seu caso para que se refaça a própria História - esses eventos [constituintes básicos de um espaço histórico] devem ser habitados de referenciamento, de concretude. A História para Ngunga é ou não é.

\section{Considerações finais}

A lucidez prática dessa geração da síntese a qual pertence Ngunga fará acontecer História quando se evidencia os aspectos fundamentais dos eventos históricos, não antes! O que quero dizer é que a "explicação africana da história, assim, não parece basear-se na interpretação imediatamente lógica e científica, mas em categorias estruturais imanentes que permeiam a existência social: a imanência intemporal é decisiva para a existência qualitativa do grupo enquanto representação coletiva total" (LEITE, 1979, p. 6).

E isso fica muito claro na reação do menino quando sabe do comprometimento de Wassamba. Depois de travado o primeiro contato, ele volta decidido a lutar contra essa prática. Sentou-se ao lado de Mavinga, "Parecia mais velho, preocupado" (PEPETELA, 1981, p. 53). Após o relato daquilo que tomara conhecimento, as duras palavras do Comandante o empurram, ainda mais, para um silenciamento de reflexão: “ - Tu és muito novo. Queres lutar para melhorar a vida de todos. Para isso tens de estudar. Com Wassamba não o poderás fazer. Serás homem casado, terás de trabalhar para lhe dar de comer” (PEPETELA, 1981, p. 54). "Oh, este mundo está todo errado! Nunca se pode fazer o que se quer!" "Hei-de lutar para acabar com a compra das mulheres - gritou Ngunga raivoso. - Não são bois!” (PEPETELA, 1981, p. 54). Nas palavras do menino, a situação limite entre o arcaico-tradicional e o Novo-revolucionário é também a última escala do menino e de Angola rumo à tomada de consciência plena e ao Estado-Novo, pois, até então, houve uma flexibilização construtiva dos eventos históricos, mas a privação do amor é demasiadamente dolorosa e intolerável. O amor tem uma conotação importante nesta parte da narrativa. Já tendendo a silenciar-se num espaço redimensionado de sua travessia, Ngunga abrevia sua viagem justamente pela injustiça que se apresenta com a impossibilidade do amor. Wassamba foi comprada, o que não permite que ela se afaste dos limites espaciais do kimbo. Como já havia dito, a menina tem papel fundamental para que a narrativa não se configure trágica. É ela que não aceita fugir com Ngunga, perpetuando uma tradição secular de alembamento $^{8}$, para impedir que seus pais tenham que devolver a quota de casamento, mas essa atitude também é a possibilitadora da liberdade basilar para a luta de Ngunga. É por ela e por esta razão concreta que Ngunga transcende, sem hesitar, sua condição de menino/homem. A decisão final foi adiada, ficou para depois, no momento em que as mulheres começarem a dançar a Chinjanguila, todos irão estar distraídos, os homens estarão bebendo e, então, terão tempo para conversar. A dança não demorou e os dois fugiram para a mata. "Calaram-se. As palavras não tinham sentido, Ngunga sempre desconfiara das palavras, sobretudo em certos momentos" (PEPETELA, 1981, p. 56), o silêncio se fez autoridade, impôs um hiato de reflexão, de posicionamento objetivo em relação às coisas. Um momento perpetuado nos dias e noites do país que surgia ali, junto com um-outro-Ngunga.

\footnotetext{
${ }^{8}$ Em As aventuras de Ngunga a prática do alembamento está referida exclusiva e redutoramente à compra de mulheres, quando em verdade o alembamento tem uma significação bem mais complexa: ele é uma espécie de indenização pela força de trabalho, uma vez que o conhecimento milenar do cultivo e a força da mão-de-obra migram da família da mulher para a família do marido. A visão reducionista entende-se porque a obra tinha um objetivo claro: o de alfabetizar guerrilheiros adultos, iniciando um trabalhoso processo de ruptura com paradigmas tradicionais seculares.
} 
- Mudei muito agora, sinto que já não sou o mesmo. Por isso mudarei também de nome. Não quero que as pessoas saibam quem fui eu.

- Nem eu?

- Tu podes saber. Só tu! Se um dia quiseres podes avisar-me para eu vir buscar-te. Escolhe meu novo nome.

Wassamba pensou, pensou, apertando-lhe a mão. Encostou a boca ao ouvido dele e pronunciou uma palavra. Mas fê-lo tão baixinho que o barulho da chinjanguila a cobriu e só Ngunga pôde perceber (PEPETELA, 1981, p. 56).

Neste exato instante da tessitura narrativa de Pepetela, o personagem Ngunga vetoriado por um amor, enterra um passado de tradições injustas e cruéis. Um passado habitado de Chipoyas, Cozinheiros e Kafuxis, para que nasça, então, um Estado-outro [tão estranho e alheio como o próprio Ngunga-é-pra-ele-mesmo] sem o ranço da tradição pesando às costas, sem o homem negando ao homem comida. Neste instante, um Homem nasceu dentro do pequeno Ngunga, um Novo-Homem está surgindo definitivamente na África, conscienteconstrutor da justiça. Um ser que tem a visão global de sua terra, andarilho-viajante conhecedor das necessidades que emergem do meio social e migram para um-eu-traumatizado historicamente. Muito relevante a travessia de Ngunga, pois constrói durante toda a narrativa a tensão do trajeto e, quando atinge o ápice, usa um artifício tradicional para transcender a fronteira-limiar. Ensina Cassier que

[...] para a concepção mítica fundamental, a individualidade humana não é algo simplesmente fixo e imutável, mas algo que, a cada passo, em uma nova fase decisiva da vida, ganha um outro ser, um outro eu, esta transformação também se exprime, antes de tudo, na troca do nome. Na sagração da puberdade, o rapaz recebe outro nome, visto que, através dos ritos mágicos que acompanham a iniciação, deixou de existir como menino, renascendo como um outro, um homem, no qual se reencarnou um de seus antepassados. Outras vezes, a troca de nome deve servir para proteger o homem contra um perigo iminente; o ameaçado se subtrai ao perigo, na medida em que, com o nome nôvo, atrai de certo modo um eu diferente, cujo envoltório o torna irreconhecível (CASSIRER, 1972, p. 70).

O espectro sacro da transcendência do menino legitima a contestação e a apropriação das tradições culturais, uma vez que se mostra bastante clara a edificação final da passagem e da construção do que vim falando durante esse texto: o surgimento, devido às transformações da malha social, de um homem africano que difere daquele que historicamente se apresentou - um homem silencioso se ergue, repleto de significações e rupturas, o que relega a palavra vazia e grosseira à condição da esterilidade nominativa, à composição do discurso colonialista [historicamente falido].

Bibliografia

ABDALA JUNIOR, B. Literatura, história e política. São Paulo: Ática, 1989.

AGUIAR E SILVA, V. M. de. Teoria da literatura. Coimbra: Almedina, 1992.

ANDRADE, F. da C. Literatura angolana: opiniões. Lisboa: Edições 70, 1980.

ANDRADE, M. C. de. Imperialismo e fragmentação do espaço. São Paulo: Unicamp, 1991.

ARISTÓTELES; HORÁCIO; LONGINO. A poética clássica. São Paulo: Cultrix, 1997.

ARMSTRONG, K. Breve história do mito. São Paulo: Cia das Letras, 2005.

BACHELARD, G. A chama de uma vela. Rio de Janeiro: Bertrand Brasil, 1989.

. A poética do devaneio. São Paulo: Martins Fontes, 1996.

. A poética do espaço. São Paulo: Martins Fontes, 1998.

BHABHA, H. K. O local da cultura. Belo Horizonte: Editora da UFMG, 2007.

BAKHTIN, M. Problemas da poética de Dostoiévski. Rio de Janeiro: Forense Universitária, 1981.

. Marxismo e filosofia da linguagem. 6. ed. São Paulo: Hucitec, 2004.

. Questões de literatura e de estética: a teoria do romance. 3. ed. São Paulo: Hucitec,1993a.

. A cultura popular na Idade Média e no Renascimento: o contexto de François Rabelais. São Paulo:

Hucitec, 1993b.

BARTHES, R. Mitologias. Rio de Janeiro: Bertrand Brasil, 1993.

O rumor da língua. São Paulo: Brasiliense, 1988.

BOAVIDA, A. Angola: cinco séculos de exploração portuguesa. Rio de Janeiro: Civilização Brasileira, 1967. 
BOURDIEU, P. O poder simbólico. Rio de Janeiro: Bertrand Brasil, 2005.

BRAIT, Beth (Org.) Bakthin: dialogismo e construção do sentido. São Paulo: Unicamp, 1997.

BRUNSCHWIG, H. A partilha da África negra. São Paulo: Perspectiva, 2004.

BURKE, P. (Org.) A escrita da história: novas perspectivas. São Paulo: Editora da Unesp, 1991.

BURKE, P. A Escola dos Annales. São Paulo: Unesp, 1997.

. Hibridismo Cultural. São Leopoldo: Unisinos, 2003.

CANÊDO, L. B. A descolonização da Ásia e da África. São Paulo: Unicamp, 1986.

CARVALHAL, T. F, Literatura comparada. São Paulo: Ática, 1999.

CASSIRER, E. O mito do Estado. Lisboa: Europa-América, 1961.

Linguagem e mito. São Paulo: Perspectiva, 1972.

CASTORIADES, C. A instituição e o imaginário: primeira abordagem. São Paulo: Cultrix, 1972.

CÉSAIRE, A. Discurso sobre o colonialismo. Lisboa: Livraria Sá da Costa Editora, 1978.

CHAVES, R. et alli (Org). Brasil/África: como se o mar fosse mentira. São Paulo: Editora da Unesp, 2006.

CHEVALIER, J.; GHEERBRANDT, Alain. Dicionário de Símbolos. Rio de Janeiro: José Olympio, 2000.

DACOSTA, F. Máscaras de Salazar. Lisboa: Notícias editorial, 1998.

DURAND, G. Imagens e reflexos do imaginário português. Lisboa: Hugin, 1997.

O imaginário: ensaio acerca das ciências e da filosofia da imagem. Rio de Janeiro: Difel, 1999.

ELIADE, M. Mito do eterno retorno. São Paulo: Mercuryo, 1992.

Mito e realidade. São Paulo: Perspectiva, 1994.

FRANÇOIS, F. Dialogismo e romance ou Bakhtin visto através de Dostoiévski. In: BRAIT, B. Bakthin: dialogismo e construção do sentido. São Paulo: Unicamp, 1997

FERRO, M. (Org.). O livro negro do colonialismo. Rio de Janeiro: Ediouro, 2004.

HALL, S. A identidade cultural na pós-modernidade. Rio de Janeiro: DP\&A, 1999.

Da diáspora: identidades e mediações culturais. Belo Horizonte: Editora de UFMG, 2003.

GONZAGA, N. Angola: pequena monografia. Lisboa: Agência Geral do Ultramar, 1965.

HEGEL, F. Lecciones sobre la filosofía de la historia universal. Madrid: Alianza Editorial, 1986.

HOBSBAWM, E. Era dos extremos: o breve século XX 1914-1991. São Paulo: Cia das Letras, 1994.

LARANJEIRA, P. Ensaios afro-literários. Coimbra: Novo Imbondeiro, 2001.

MENEZES, S. Mamma Angola. Sociedade e economia de uma país nascente. São Paulo: Edusp, 2000.

MELETÍNSKI, E. M. A poética do mito. Rio de Janeiro: Forense Universitária, 1987.

. Os arquétipos literários. Cotia: Ateliê, 2002.

MEMMI, A. Retrato do colonizado precedido pelo retrato do colonizador. Rio de Janeiro: Paz e Terra, 1977.

PADILHA, Laura Cavalcante. Novos pactos, Outras ficções: Ensaios sobre literaturas Afro-luso-brasileiras.

Porto Alegre: EDIPUCRS, 2002.

PATAI, Raphael. O mito e o homem moderno. São Paulo: Cultrix, 1972.

PAZ, O. El arco y la lira. Buenos Aires: Alfaguara, 1972.

PEPETELA. As aventuras de Ngunga. São Paulo: Ática, 1981.

Mayombe. São Paulo: Ática, 1982.

. Yaka. São Paulo: Ática, 1984.

. Lueji: o nascimento dum império. Lisboa: Dom Quixote, 1990.

- A geração da utopia. Rio de Janeiro: Nova Fronteira, 2000.

. O cão e os caluandas. 3. ed. Lisboa: Dom Quixote, 1996a.

. Parábola do cágado velho. Lisboa: Dom Quixote, $1996 \mathrm{~b}$.

. O desejo de Kianda. Lisboa: Dom Quixote, 1997.

REMÉDIOS, Ma . L. R. O romance português contemporâneo. Santa Maria: UFSM, 1986.

RIBEIRO, L.D.T. "Descolonização africana". In: Ciências e Letras: Revista da Faculdade Porto-Alegrense de Educação, Ciência e Letras. FAPA. 1998. 21/22.

SAID, E. W. Cultura e imperialismo. São Paulo: Companhia das Letras, 1999. . Orientalismo. São Paulo: Companhia das Letras, 1999.

SARAIVA, A, J e LOPES, Ó. História da literatura portuguesa. 16 ed. Porto: Porto, 1993.

SARAIVA, J. F. S. O lugar da África. Brasília: UNB, 1996. . Angola e Brasil nas rotas do Atlântico. Rio de Janeiro: Bertrand Brasil, 1999.

SCIACCA, M.F. Silêncio e palavra. Porto Alegre: Faculdade de Filosofia -UFRGS, 1967.

SHARPE, J. A história vista de baixo. In: BURKE, Peter. (Org.) A escrita da história. Novas perspectivas. São Paulo: Unesp, 1992. p.39-62. 
SILVA, A. da C. e. Um rio chamado Atlântico: a África no Brasil e o Brasil na África. Rio de Janeiro: Nova Fronteira, 2003.

SILVA, $\mathrm{M}^{\mathrm{a}}$ T. As aventuras de Ngunga: uma mitologia invertida. Revista África: Literatura e Cultura, Lisboa, v. 2, n. 10, Ano II, out./dez. 1980.

STEINER, G. Linguagem e silêncio: ensaios sobre a crise da palavra. São Paulo: Cia das Letras, 1988.

. Lenguaje y silencio: ensayo sobre la literatura, el lenguaje y lo inhumano. Barcelona: Gedisa, 2003.

TEZZA, C. A construção de vozes no romance. In: BRAIT, Beth (Org.). Bakthin: dialogismo e construção do sentido. São Paulo: Unicamp, 1999.

TUTIKIAN, J. Inquietos olhares: a construção do processo de identidade nacional nas obras de Lídia Jorge e Orlanda Amarílis. São Paulo: Arte e Ciência, 1999.

Velhas identidades novas: o pós colonialismo e a emergência das nações de língua portuguesa.Porto Alegre: Sarga Luzzatto, 2006.

Van GENNEP, A. Os ritos de passagem: estudo sistemático dos ritos da porta e dasoleira, da hospitalidade, da adoção, gravidez e parto, nascimento, infância, puberdade, iniciação, coroação, noivado, casamento, funerais, estações, etc. Trad. Mariano Ferreira. Petropólis, 1977.

ZOPPI-FONTANA, M. G. O outro da personagem: enunciação, exterioridade e discurso. In: BRAIT, Beth (org.) Bakthin: dialogismo e construção do sentido. São Paulo: Unicamp, 1997. 